\title{
PERAN PSYCHOLOGICAL CAPITAL DALAM MEMBANGUN MENTAL ENTREPRENEUR DI MASA PANDEMI COVID-19
}

\author{
Diana Harding, Anissa Lestari Kadiyono dan Kartika Nuradina \\ Fakultas Psikologi, Universitas Padjajaran \\ E-mail: dhard_harding@yahoo.com
}

\begin{abstract}
ABSTRAK. Situasi pandemi COVID-19 yang mulai menyebar sejak awal tahun 2020 di Indonesia menimbulkan berbagai dampak yang berpengaruh kepada perekonomian masyarakat yang ditandai dengan meningkatnya jumlah pengangguran dan kasus PHK. Di sisi lain, masyarakat dituntut untuk mencari mata pencaharian baru agar mampu memenuhi kebutuhan hidup di masa pandemi. Melalui latar belakang ini, penulis menginisiatif kegiatan pengabdian masyarakat dalam bentuk Kuliah Kerja Nyata Program Pengabdian Mahasiswa (KKN-PPM) yang melibatkan mahasiswa untuk berbagi ilmu dengan masyarakat dalam tema kewirausahaan (entrepreneurship). Tujuan dari artikel penelitian ini adalah memberikan berbagai inisiatif yang dapat dilakukan masyarakat dalam menghadapi tantangan di masa pandemi, terutama dari perspektif kewirausahaan. Di sisi lain, dalam artikel ini dibahas pula berbagai intervensi yang dapat dilakukan dari akademisi, pemerintah, dan Lembaga Swadaya Masyarakat (LSM) terkait peningkatan kesadaran mengenai jiwa kewirausahaan masyarakat dengan meninjau aspek-aspek psychological capital untuk menggambarkan kesiapan masyarakat sebagai individu dalam menguasai kompetensi sebagai wirausaha. Penelitian dilakukan pada 216 orang dan terdapat hasil bahwa optimism perlu ditingkatkan pada mahasiswa dalam membangun mental entrepreneur di masa yang akan datang.
\end{abstract}

Kata Kunci: kewirausahaan; pengabdian masyarakat; KKN-PPM; Pandemi Covid-19

\begin{abstract}
The COVID-19 pandemic situation that began to spread since the beginning of 2020 in Indonesia caused various impacts that had an impact on the community's economy, which was marked by an increase in the number of unemployed and cases of layoffs. On the other hand, the community is required to find new livelihoods in order to be able to meet the needs of life during the pandemic. Through this background, the author initiated community service activities in the form of a Student Service Program Real Work Lecture which involved students to share knowledge with the community on the theme of entrepreneurship. The purpose of this research article is to provide various initiatives that can be carried out by the community in facing challenges during the pandemic, especially from an entrepreneurial perspective. On the other hand, this article also discusses various interventions that can be carried out from academia, government, and Non-Governmental Organizations (NGOs) related to increasing awareness about the entrepreneurial spirit of the community by reviewing aspects of psychological capital to describe the readiness of the community as individuals in mastering competencies as a Entrepreneur. The study was conducted on 216 people and there were results that optimism needed to be increased in students in building entrepreneurial mentality in the future.
\end{abstract}

Keywords: entrepreneurship; internship; community development; Covid-19 pandemic

\section{PENDAHULUAN}

Wabah COVID-19 yang mulai menyebar sejak awal tahun 2020 menjadi permasalahan baru untuk berbagai negara di dunia, termasuk Indonesia. Virus Covid-19 tersebut kemudian ditetapkan sebagai pandemi global oleh World Health Organization (WHO) pada tanggal 12 Maret 2020 (Baskara, 2020). Semenjak ditetapkannya Virus Covid-19 sebagai pandemi, diketahui pula bahwa Indonesia pun menjadi salah satu negara yang ikut terpapar virus tersebut sejak tanggal 2 Maret 2020 (Nuraini, 2020).

Berbagai kebijakan dari pemerintah untuk menekan angka pertumbuhan kasus penye-baran virus dilakukan melalui implementasi pembatasan sosial berskala besar (PSBB) dan penerapan berbagai protokol kesehatan. Di satu sisi, kebijakan-kebijakan ini bertujuan untuk menekankan pentingnya aspek kesehatan, tapi di sisi lain, terdapat efek samping pada berbagai dimensi sosial-ekonomi. Seiring berbagainya penerapan pembatasan aktivitas di ruang publik, kondisi perekonomian pun menjadi melemah dan mengakibatkan berbagai penyesuaiaan dilakukan, contohnya dengan cara Pemutusan Hubungan Kerja (PHK) yang kemudian memberikan dampak lanjutan akan meningkatnya angka pengangguran di berbagai wilayah di Indonesia. Menurut data Kementerian Ketenagakerjaan per 20 April 2020, sebanyak 2.084 .593 pekerja dari 116.370 perusahaan dirumahkan dan terkena Pemutusan Hubungan Kerja (PHK).

Dibutuhkan suatu intervensi dan kebijakan untuk menangani isu perekonomian, mengingat kondisi pandemi yang masih membutuhkan waktu penyesuaian melalui implementasi pro-tokol kesehatan dan pemberian vaksin. Salah satu bentuk intervensi yang dapat dilakukan adalah melalui pembekalan materi kepada masyarakat mengenai konsep dan bekal praktis untuk memulai dan mengembangkan usaha di masa pandemi sebagai alternatif sumber mata pencahariaan baru.

Hal ini menjadi salah satu langkah yang paling memungkinkan, mengingat terbatasnya ruang 
masyarakat mencari pekerjaan akibat Pandemi Covid-19. Maka, menjadi seorang wirausaha merupakan salah satu langkah tepat yang bisa diupayakan berdasar pada potensi diri yang mereka miliki masing-masing. Namun, fokus utama yang dapat dipersiapkan pada masyarakat bahwa tantangan memulai usaha baru serta pengembangan jiwa kewirausahaan memerlukan suatu proses yang matang, salah satunya dengan mendapat pelatihan dan pembelajaran.

Pada artikel penelitian ini, penulis bekerja sama dengan tim mahasiswa dalam payung program Kuliah Kerja Nyata Program Peng-abdian Mahasiswa (KKN-PPM) sebagai bentuk kegiatan pengabdian masyarakat dalam memberikan kontribusi nyata pada penerapan ilmu yang telah dipelajari di lingkungan kampus kepada masyarakat luas. Hal ini juga sesuai dengan salah satu poin dari Tridarma Perguruan Tinggi, yaitu pendidikan, penelitian, dan pengabdian kepada masyarakat. Di dalam gaya hidup baru yang bertransformasi di masa pandemi, atau sering disebut juga sebagai new normal, terdapat berbagai perubahan untuk menjamin protokol kesehatan tetap terjaga dan mencegah penyebaran COVID-19. Dunia pendidikan dan lingkungan kampus adalah salah satu pionir melalui berbagai inovasi dalam gaya hidup baru dari new normal, sebagai contoh adalah melalui pemanfaatan ruang kelas virtual, media sosial, dan berbagai teknologi praktis lainnya yang mempermudah alur komunikasi.

Berdasarkan pertimbangan di atas, tim penulis berargumen bahwa kerjasama antara mahasiswa dan masyarakat melalui pembekalan materi kewirausahaan dalam bentuk webinar dan kelas virtual dapat berkontribusi untuk meningkatkan pengetahuan masyarakat terhadap peluang bisnis dan jiwa kewirausahaan di masa pandemi, dan di saat yang sama memberikan kesempatan bagi mahasiswa dalam melihat permasalahan secara langsung di lapangan dan juga memberikan kesempatan serta pengalaman untuk berperan aktif dalam menginisiasi kegiatan positif.

Dalam hal ini, tim peneliti menggunakan pendekatanpsychological capitaldalammen-jelaskan gambaran kesiapan jiwa wirausaha masyarakat dalam di masa Pandemi Covid-19, yaitu kapasitas psikologi positif yang dimiliki oleh seseorang yang berperan besar dalam menentukan keberhasilanya untuk berkembang (Luthans \& Youssef-Morgan, 2017). Individu dengan tingkat psychological capital yang tinggi menunjukkan diri yang lebih optimis, percaya diri, dan tangguh, sehingga mengharapkan hal-hal yang baik terjadi kepada dirinya sebagai wirausaha (Julianti \& Dewayani, 2015).

Kesiapan jiwa kewirausahaan setelah diberikannya pelatihan dan pembelajaran oleh tim peneliti ditinjau melalui dimensi-dimensi penyusun psychological capital, yaitu dimensi self efficacy yang merupakan adanya kepercayaan diri untuk mengambil dan melakukan upaya terhadap tugas yang menantang, dimensi optimsm yang merupakan atribusi positif masyarakat, dimensi hope yang merupakan adanya kegigihan dan kemauan mengarahkan diri pada tujuan, serta dimensi resilience yang adanya kemampuan bertahan, bangkit, atau bahkan melampaui kesulitan yang dihadapi di masa Pandemi Covid-19 (Luthans \& Youssef-Morgan, 2017).

\section{METODE}

Kegiatan KKN dengan agenda mem-bangun mental kewirausahaan di masa pandemi dilakukan dalam empat tahapan berupa (a) persiapan, (b) pelaksanaan, (c) tindak lanjut, dan (d) evaluasi. Platform sosial media (Trello; Whatsapp) dan kelas virtual (Google Meet; Zoom) digunakan sebagai media utama dalamberkomunikasiantara mahasiswa, dosen, dan masyarakat, sehingga meminimalisir kegiatan bertatap muka secara langsung.

Tahap persiapan dilakukan dengan fokus untuk koordinasi antara dosen pembimbing lapangan (DPL) dengan 20 mahasiswa KKN untuk membagi beberapa jenis materi, serta mengkaji kondisi dan situasi lapangan. Pada tahapan ini, sebagian besar kegiatan memanfaatkan platform Trello, Whatsapp, dan Google Meeting untuk berkoordinasi antar anggota. (Gambar 1).

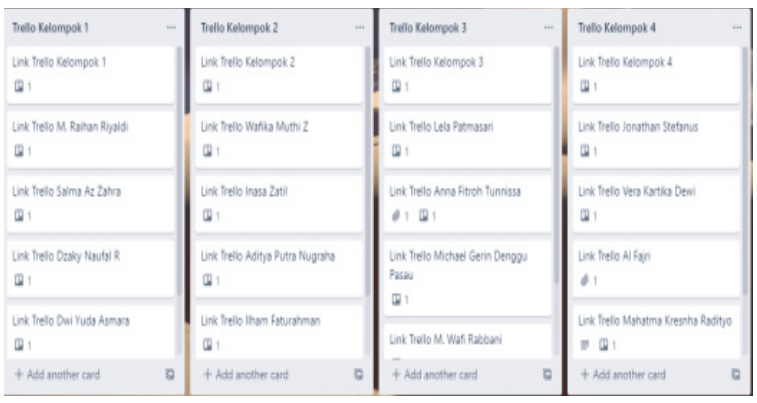

Gambar 1. Logbook Trello Koordinasi Progres Anggota KKN-PPM

Tahap pelaksaanaan dibagi menjadi dua kegiatan utama. Kegiatan pertama adalah observasi lapangan dan permasalahan oleh para mahasiswa dengan menggunakan metode wawancara dan survey. Kegiatan kedua adalah mengadakan acara webinar terkait materi membangun mental entrepreneur di masa pandemi yang bekerjasama dengan beberapa pembicara dari bidang akademisi dan praktisi sebagai narasumber. Narasumber yang diundang dalam agenda webinar ini adalah Dr. Hj. Diana Harding, M.Si., Psikolog, dan Dr. Anissa Lestari Kadiyono, M.Si., Psikolog yang merupakan narasumber dari bidang akademisi, serta dua narasumber praktisi 
pengusaha muda yaitu Rizky Yanuar dan Fathira Ismail. Acara webinar ini dilaksanakan dengan judul "Membangun Mental Entrepreneur di Masa Pandemi Covid" dan dihadiri oleh 216 partisipan.

Tahap tindak lanjut terfokuskan pada kegiatan koordinasi dan konsultasi antara mahasiswa KKN dan DPL terkait teknis lapangan. Kegiatan pengabdian masyarakat kemudian ditutup dengan tahap evaluasi yang dilakukan setelah kegiatan webinar dalam bentuk diskusi untuk poin-poin perbaikan ke depannya.

Tabel 1. Susunan Agenda Kegiatan KKN dan Acara Webinar

\begin{tabular}{llcc}
\hline \multirow{2}{*}{ Agenda } & \multicolumn{3}{c}{ Bulan } \\
\cline { 2 - 4 } & $\begin{array}{c}\text { Januari } \\
\text { Minggu } \\
\text { ke-4 }\end{array}$ & $\begin{array}{c}\text { Februari } \\
\text { Minggu } \\
\text { ke-1 }\end{array}$ & $\begin{array}{c}\text { Februari } \\
\text { Minggu } \\
\text { ke-2 }\end{array}$ \\
\hline Koordinasi Mahasiswa & & \\
\& DPL & & \\
Penyusunan rundown & & \\
webinar \\
Mengundang Narasumber \\
Persiapan Teknis Acara \\
Webinar \\
Pelaksanaan Acara (8 \\
Februari) \\
Evaluasi Acara dan \\
Penyusunan Laporan
\end{tabular}

Berdasarkan program webinar yang telah dilakukan tersebut, dapat ditinjau evaluasi terhadap program yang dijalankan terkait dimensidimensi psychological capital (Luthans, 2011) untuk menggambarkan mental entrepreneur pada masyarakat sebagaimana dijelaskan melalui pemberian post-test di akhir webinar dengan reliabilitas alat ukur yang dimiliki adalah 928 .

Analisis data diolah dengan menggunakan SPSS versi 25 for Macintosh untuk melakukan uji perbedaan dengan uji one-way anova untuk mengetahui tingkat psychological capital masyarakat dan didapatkan hasil berada pada kategori sedang dengan nilai mean skor total 3,87. Kemudia, dilakukan uji lanjutan dengan one sample t-test untuk melihat komponen dominan psychological capital pada masyarakat. Didapatkan hasil tertera pada tabel 2 .

Tabel 2. Perbandingan Mean Psychological Capital Masyarakat Jawa Barat

\begin{tabular}{lcl}
\hline \multicolumn{1}{c}{ Dimensi } & Mean Difference & Sig. \\
\hline Efficacy & 3.98 & .000 \\
Hope & 3.87 & .000 \\
Resilience & 4.00 & .000 \\
Optimism & 3.89 & .000 \\
\hline
\end{tabular}

Bila dilihat dari hasil uji beda skor pre-test dan post-test yang diberikan pada peserta, makad dididapatkan hasil seperti yang dapat dilihat dalam gambar 2.

\section{Pre-Post Test Psychological Capital}

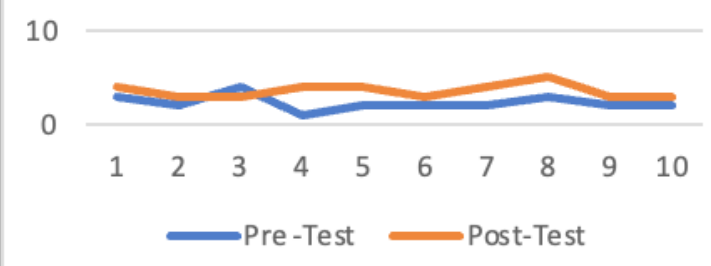

\section{Gambar 1. Pre-Post Test}

Pre-Post Test yang telah diberikan dilakukan uji beda terhadap skor total pada setiap aspek psychological capital dan hasilnya terdapat dalam tabel 3.

\begin{tabular}{lccc}
\hline Aspek & $\begin{array}{c}1 / 2 \text { p-value (one } \\
\text { tailed) Pre-test } \\
\text { - Post Test }\end{array}$ & $\begin{array}{c}\text { Koefisien } \\
\text { Alpha (a) }\end{array}$ & Kesimpulan \\
\hline Efficacy & 0,001 & 0,05 & $\mathrm{H}_{0}$ ditolak \\
Hope & 0,043 & 0,05 & $\mathrm{H}_{0}$ ditolak \\
Resilience & 0,001 & 0,05 & $\mathrm{H}_{0}$ ditolak \\
Optimism & 0,002 & 0,05 & $\mathrm{H}_{0}$ ditolak \\
\hline
\end{tabular}

Tabel 3 diatas menunjukkan p-value dari hasil uji beda untuk keempat aspek psychological capital lebih kecil dari alpha $(0,05)$ sehingga dapat disimpulkan bahwa terdapat peningkatan yang signifikan terhadap self-efficacy, harapan, resiliensi, maupun optimisme yang dimiliki oleh peserta.

\section{HASIL DAN PEMBAHASAN}

Rangkaian kegiatan KKN-PPM dalam tema besar "Praktikum Membangun Usaha Mandiri" ditujukan dalam pelaksanaannya sebagai media bagi mahasiswa untuk dapat memberikan edukasi yang baik kepada masyarakat untuk bisa bertahan di masa pandemi Covid-19. Seiring dengan dampak pandemi yang mempengaruhi kondisi perekonomian negara dan masyarakat, adanya alternatif mata pencaharian baru merupakan suatu inisiatif yang perlu digagas untuk meningkatkan kesejahteraan masyarakat yang di masa pandemi ini terancam oleh beberapa fenomena seperti Pemutusan Hubungan Kerja (PHK) dan tingkat pengangguran yang tinggi.

Kegiatan KKN-PPM dengan mengadakan program webinar dapat menjadi bentuk nyata dari intervensi kegiatan untuk solusi mata pencahariaan masyarakat. Melalui diskusi di dalam agenda webinar dengan narasumber dari pihak akademi serta praktisi dari pihak pengusaha muda, acara webinar ini dapat menjadi sarana pembekalan materi dan ilmu pengetahuan bagi masyarakat untuk membangun mental entrepreneur di masa pandemi. Dibutuhkan suatu inisiatif dan kemauan yang tinggi dari masyarakat untuk dapat menginisiasi suatu 
jenis usaha baru di lingkungannya, dan melalui pembekalan persiapan mental, maka masyarakat dapat memiliki modal motivasi ketika menghadapi berbagai tantangan dalam membuka usaha baru.

Narasumber dari pihak praktisi pengusaha berperan dalam memberikan pembekalan ilmu serta pengalaman dari pihak narasumber ketika memulai usaha yang dapat menjadi modal penting bagi para calon wirausahawan baru memulai bisnisnya. Pengalaman membuka usaha yang dibungkus dengan penyampaian yang menarik dapat menjadi sumber inspirasi serta inovasi masyarakat dalam berkreasi.

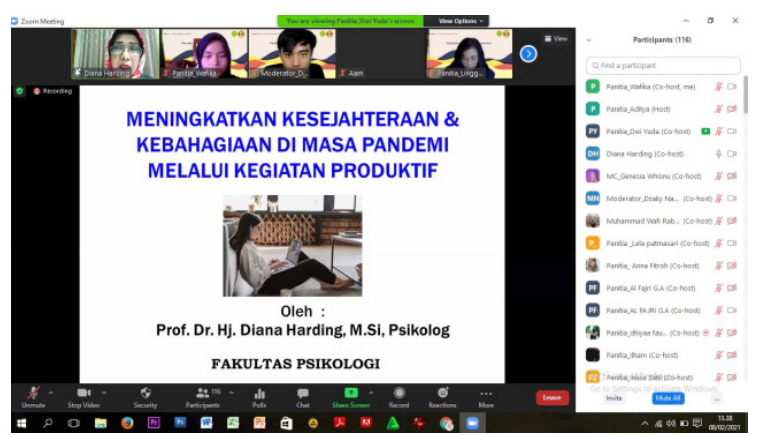

Gambar 2.Acara Webinar"Membangun MentalEntrepreneur di Masa Pandemi Covid"

Walaupun program KKN-PPM dalam mengadakan kegiatan webinar mendapat sambutan yang positif dari berbagai kalangan masyarakat, namun terdapat hal yang perlu diperhatikan dalam aspek bisnis dan kewirausahaan yaitu tingkat untung dan rugi dari pengusaha. Aspek ini sayangnya tidak dapat dimasukkan ke dalam poin webinar dikarenakan hasilnya yang bergantung dengan kondisi pasar. Dibutuhkan suatu proses berkelanjutan dan menarik untuk dipertimbangkan sebagai kegiatan ke depannya dalam memantau perkembangan para partisipan webinar yang mengimplementasikan ilmunya. Berbagai tantangan yang akan dihadapi para pengusaha muda dan hubungan antara motivasi serta pembangunan karakter yang didapatkan dari acara webinar dapat menjadi poin penelitian menarik ke depannya untuk melihat hubungan motivasi kewirausahaan.

Dalam penelitian ini didapatkan gambaran umum bahwa setelah diberikannya webinar dalam menyiapkan mental sebagai seorang wirausaha di tengah Pandemi Covid-19, masyarakat memiliki tingkat psychological capital yang berada pada kategori sedang. Hal ini menunjukkan bahwa pemberian pembekalan persiapan mental kewirausahaan pada masyarakat cukup berperan dan diperlukan pembekalan-pembekalan berikutnya diiringi dengan upaya praktik untuk menambah pengalaman masyarakat.

Psychological Capital adalah kondisi positif yang dimiliki individu, yang dikembangkan melalui rasa percaya diri dapat mengatasi masalah (efficacy), optimism menuju masa depan yang lebih cerah, dapat mengatasi masalah dalam mencapai tujuan dengan mengembangkan harapan (hope), dan dapat bangkit dari kegagalan (resilience) (Luthans, Youssef, et al., 2007).

Psychological Capital dapat mengarahkan diri individu memiliki sikap dan mengarahkan diri menampilkan perilaku melalui evaluasi diri, kepribadian yang dimiliki, serta kesesuaiannya dengan pekerjaan (Avey, Luthans, \& Youssef, 2010). Penelitian yang dilakukan menunjukkan bahwa Psychological capital dapat meningkatkan mental berwirausaha responden. Hal ini sesuai dengan penelitian yang dilakukan oleh Roche \& Luthans (2014) bahwa entrepreneur dapat ditingkatkan melalui psychological capital yang dimilikinya sebesar 27\% sampai 37\%.

Psychological Capital akan meningkatkan kemampuan individu dalam mengembangkan kepemimpinan, kemampuan menghadapi pelanggan, menjalin hubungan kemitraan, mengembangkan kemampuan bekerja sama dalam tim, negosiasi, dan kemampuan mengatasi masalah yang membuatnya mampu meningkatkan mental wirausaha (Borg \& Johnston, 2013; Chin, Raman, Yeow, \& Eze, 2012; Humphrey, 2013 dalam Baluku, 2018).

Penelitian lain menunjukkan bahwa entrepreneur sebaiknya memiliki rasa percaya diri yang dibangun dari Latihan-latihan kecil yang menunjukkan kiprah saat ini (Digan, 2019)

Komponen psychological capital masyarakat dalam hal ini didominasi oleh dimensi resilience, diikuti dengan besarnya dimensi self efficacy, optimism, dan hope. Artinya, kesiapan masyarakat dalam berwirausaha banyak didominasi oleh kesiapan mereka untuk bangkit kembali dari keadaan sulit yang mereka alami khsususnya dalam kondisi Pandemi Covid-19. Tentu ini akan menjadi sumber kekuatan utama mental seorang wirausaha ketika masyarkat mulai terjun di masa depan.

Menurut Luthans (2007) bahwa keempat komponen psychological capital ini tidak hanya bersifat saling mempengaruhi, namun juga bekerja secara sinergis dalam membangun psychological capital yang dimiliki oleh individu dalam menyelesaikan suatu tugas. Sehingga komponen lainnya tentu akan ikut berkontribusi dalam mempersiapkan jiwa wirausaha masyarakat.

Pengujian hasil dari pemberian intervensi untuk meningkatkan mental wirausaha masyarakat melalui psychological capital memberikan pengaruh yang signifkan. Peserta mendapatkan peningkatan di keempat aspek psychological capital yang akan mempengaruhi pembentukan mental berwirausaha. 


\section{SIMPULAN}

Kegiatan Kuliah Kerja Nyata Pengabdian Pada Masyarakat (KKN-PPM) dengan tema kewirausahaan "Praktikum Membangun Usaha Mandiri" telah dilaksanakan dengan fokus menggunakan pendekatan daring yang mulai marak digunakan di masa pandemi. Melalui kegiatan webinar virtual dengan judul "Membangun Mental Entrepreneur di Masa Pandemi", sebagai suatu bentuk intervensi telah berhasil meningkatkan mental wirausaha peserta dengan memberikan modal pengetahuan dan membangun mental entrepreneur yang merupakan aspek penting dalam membuka usaha. Melalui program kerjasama antara mahasiswa dan masyarakat, kegiatan ini dapat menjadi bentuk implementasi nyata dari Tridarma Perguruan Tinggi, dan diharapkan program inib dapat memberikan pula keluaran berupa munculnya pengusaha baru yang dapat memberikan feedback positif untuk berkontribusi di dalam memulihkan kondisi perekonomian negara, serta mampu menginspirasi lingkungan disekitarnya.

Dalam hal ini dapat diberikan saran praktis kepada akademisi, pemerintah, maupun LSM agar kemudian dapat meninjau komponen kesiapan masyarakat dalam membangun mental dan jiwa wirausaha melalui pendekatan komponen psychological capital yang masih belum optimal, sehingga didapatkan jiwa masyarkat yang siap secara mental dan psikologis untuk menjadi seorang wirausaha di masa depan sebagai upayanya bangkit dari dampak Pandemi Covid-19.

\section{DAFTAR PUSTAKA}

Avey, J. B., Luthans, F., \& Youssef, C. M. (2010). The additive value of psychological capital: Predicting positive and negative work attitudes and behaviors. Journal of Management, 36, 430-452. doi: 10.1177/0149206308329961
Baluku, M. M., Kikooma, J. F., Bantu, E., \& Otto, K. (2018). Psychological capital and entrepreneurial outcomes: the moderating role of social competences of owners of microenterprises in East Africa. Journal of Global Entrepreneurship Research, 8(1), 1-23.

Baskara, B. (2020). Rangkaian Peristiwa Pertama Covid-19 - Bebas Akses. Kompas. https:// bebas.kompas.id/baca/riset/2020/04/18/ rangkaian-peristiwa-pertama-covid-19/

Digan, S. P., Sahi, G. K., Mantok, S., \& Patel, P. C. (2019). Women's perceived empowerment in entrepreneurial efforts: the role of bricolage and psychological capital. Journal of Small Business Management, 57(1), 206-229.

Kemenkeu. (2021, February). Pulih lebih cepat. Majalah Media Keuangan, XIV(162).

Luthans, F. (2005). Organizational Behavior, New York: McGraw-Hill, Inc.

Luthans, F., Youssef, C. M., \& Avolio, B. J. (2007). Psychological capital: Developing the human competitive edge. Oxford University Press.

Luthans, F., \& Youssef-Morgan, C. M. (2017). Psychological Capital: An Evidence-Based Positive Approach. Annual Review of Organizational Psychologyand Organizational Behavior, 4, 339-366. https://doi.org/10.1146/ annurev-orgpsych-032516-113324

Nuraini, R. (2020). Kasus Covid-19 Pertama, Masyarakat Jangan Panik | Indonesia.go.id. Indonesia.Go.Id. https://indonesia.go.id/narasi/ indonesia-dalam-angka/ekonomi/kasus-covid19-pertama-masyarakat-jangan-panik

Roche, M., Haar, J. M., \& Luthans, F. (2014). The role of mindfulness and psychological capital on the well-being of leaders. Journal of occupational health psychology, 19(4), 476. 